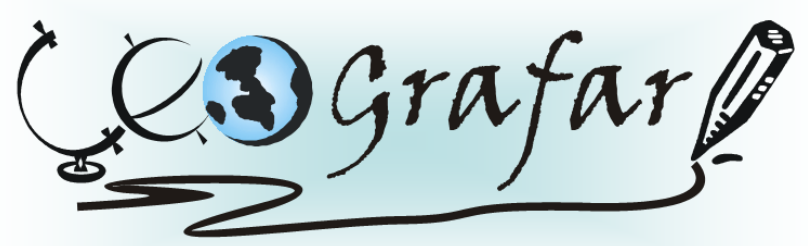

Revista Eletrônica do Programa de Pós-Graduação em Geografia - UFPR

\title{
A PEDOGÊNESE E A DISTRIBUIÇÃO DOS ELEMENTOS MAIORES E TRAÇOS NUM SISTEMA DE SOLO LATERITICO-PODZOLIZADO NA ALTA BACIA DO RIO PRETO-MG
}

\section{THE PEDOGENESIS AND DISTRIBUTION OF MAJOR AND TRACE ELEMENTS IN SOIL SYSTEM LATERITIC PODZOL IN UPPER PRETO RIVER BASIN-MG}

\author{
(Recebido em 30.04.2015; Aceito em: 11.10.2015)
}

\author{
Cristiane Regina Michelon \\ Prof. Dra. do Departamento de Geografia \\ Universidade Federal do Mato Grosso \\ Cuiabá, MT, Brasil \\ e-mail: cristianemichelon@yahoo.com.br \\ Nadia Regina do Nascimento \\ Prof. Dra. do Departamento de Planejamento \\ Territorial e Geoprocessamento \\ Universidade Estadual Paulista Júlio de Mesquita Filho \\ Rio Claro, SP, Brasil \\ e-mail: nascir@unesp.br
}

\begin{abstract}
RESUMO
A distribuição dos elementos maiores e traços permitem inúmeras interpretações sobre o sobre o solo, desde a natureza dos seus materiais (aloctonia, autoctonia) e principalmente, sobre os processos maiores atuantes, através da concentração ou exportação dos elementos ao longo do perfil. O Ti, Th e Zr são elementos que ocorrem em minerais muito resistentes ao intemperismo no ambiente pedológico. Nos perfis lateríticos formados in situ, é normal encontrar teores mais elevados destes elementos no solo do que rocha matriz. Com o objetivo de verificar o comportamento e a distribuição dos elementos num sistema de solo lateriticopodzolizado, fez-se o cálculo do balanço de massa para os elementos maiores Al e Fe e para os elementos traços Th e Ti. A área de estudo compreende a Alta Bacia do Rio Preto. Localiza-se no município de São Gonçalo do Rio Preto, dentro do Parque Estadual do Rio Preto, cerca de $30 \mathrm{Km}$ de Diamantina, região centronorte do Estado de Minas Gerais. Os resultados demonstraram aumento da depleção da maioria dos elementos em direção à jusante da topossequencia, de
\end{abstract}


TR2 a TR9. Essa tendência é reflexo da dinâmica imposta pela podzolização. Em contrapartida, os ganhos de Ti observados em TR2 estao associados ao processo de lateritização, que sob esse processo tem tendência a acumular-se, embora uma perda progressiva já é percebida em direção ao topo do perfil. Isso confirma que a podzolização já está em processo em direção a montante da topossequência.

Palavras-chave: Pedogênese, elementos traços, lateritização, podzolização.

\begin{abstract}
The distribution of major and trace elements allow many interpretations about the soil, from the nature of its material (allochthonous, autochthonous) and mainly on the larger processes acting, through concentration or export of elements along the profile. The $\mathrm{Ti}$, $\mathrm{Th}$ and $\mathrm{Zr}$ are elements that occur in minerals very resistant to weathering in pedological environment. In lateritic profiles formed in situ, it is normal to find higher levels of elements, Ti, Th e $\mathrm{Zr}$, in the soil than the material parent. In order to verify the behavior and the distribution of elements in lateritic-podzol soil system was made the calculation of the mass balance for the major elements $\mathrm{Al}$ and Fe and the trace elements Th and Ti. The study area comprises Upper Basin of the Rio Preto. Located in São Gonçalo do Rio Preto, in the Park River Preto, about 30 km of Diamantina, the central-north of the state of Minas Gerais. The results showed increased depletion of most elements toward the downstream of toposequence of TR2 to TR9. This trend reflects the dynamics imposed by podzolization. In contrast, $\mathrm{Ti}$ gains observed in the TR2 are associated lateritization process, which in this case tends to accumulate, although a progressive loss is already perceived towards the top of the profile. This confirms that the podzolization already in the process towards upstream of topossequence.
\end{abstract}

Keywords: Pedogenesis, trace elements, lateritization, podzolization

\title{
INTRODUÇÃO
}

Nas condições tropicais úmidas a lateritização constitui-se no processo dominante responsável pela formação do solo. Caracteriza-se pela acumulação residual de ferro e alumínio, com significativa perda de sílica e elementos mais solúveis como os alcalinos e alcalinos-terrosos, através da drenagem livre; bem como possíveis neoformações de outros minerais, tais como a caulinita.

As condições climáticas do meio tropical úmido e as condições do meio geoquímico (drenagem livre ou parcialmente livre, $\mathrm{pH}$ moderadamente ácido) conduzem a via de alteração hidrolítica, que caracteriza-se por forte 
dessilicatização dos minerais primários (MELFI \& PEDRO, 1977). Na alteração hidrolítica em áreas de pluviosidade elevada e boa drenagem os cátions básicos e o Si são mobilizados. A exportação dos primeiros é total e a do Si tem como principal fator de controle o grau de abertura do meio: Se os meios são abertos, sua exportação pode ser total (hidrólise total); se os meios são parcialmente abertos, parte do Si pode neoformar com o Al, argilominerais de baixa atividade (monossialitização). No primeiro caso, ocorre a solubilização total da sílica, permanecendo os elementos menos móveis (ferro e alumínio) que se precipitam, dando origem aos óxidos e hidróxidos de ferro e alumínio (goethita, hematita, gibsita) (FRITZ \& TARDY, 1974). No segundo caso, parte da sílica e a totalidade dos cátions são mobilizados e lixiviados do sistema; a parcela de sílica não exportada pela drenagem apresenta-se em forma de quartzo residual não alterado (DELVIGNE, 1965) e em forma de argilas neoformadas 1:1, como caulinita e halloysita, resultantes da recombinação do alumínio e da sílica presentes no sistema (LUCAS et al., 1996). As lateritas se formam em meios predominantemente oxidantes. Os complexos organometálicos podem se formar nos horizontes mais superficiais, mobilizando Si, Fe e Al mas são bloqueados ainda no topo do perfil (LUCAS et al., 1996), onde a matéria orgânica sofre mineralização ou é adsorvida pelas argilas (BRAVARD \& RIGHI, 1990).

Em contrapartida, os espodossolos caracterizam-se por apresentarem perfis com forte diferenciação vertical, diagnosticados pela presença de um horizonte espódico, onde se acumulam matéria orgânica e compostos organometálicos ou inorgânicos de Fe e AI (PETERSEN, 1984, LUNDSTROM et al., 2000). Sobre os horizontes espódicos existe um horizonte eluvial (HA ou HE), arenoso que nos espodossolos gigantes pode ultrapassar $10 \mathrm{~m}$ de espessura.

O mecanismo principal na gênese dos espodossolos é denominado de ácido-complexólise, e conjuga ambiente ácido ( $\mathrm{pH}$ entre 3 e 5) com a ação complexante dos ácidos orgânicos, criando condições favoráveis para a mobilização do Fe, do Al e da matéria orgânica. Os ácidos orgânicos formados pela decomposição da matéria orgânica acumulada na superfície do solo (BUOL et al., 1997) e pela transpiração de raízes, fungos e microorganismos (LUNDSTRÖM et al., 2000) reduzem o pH do meio, dando início ao processo 
de acidólise. Esses ácidos têm a capacidade de complexar o ferro e o alumínio, deixando-os dissolvidos e mobilizados no solo (TOLEDO et al., 2000); a partir da alteração e solubilização dos constituintes primários do solo (MELFI \& PEDRO, 1978). Os produtos da complexação são, então, eluviados e precipitados no horizonte Bh em fases pobremente cristalinas e inorgânicas de Fe, Al e Si (LUNDSTRÖM et al., 2000). O resíduo dessa alteração agressiva é o quartzo, constituinte quase exclusivo do horizonte $E$, uma vez que o Si é o elemento menos solúvel nesse ambiente. As águas que drenam os espodossolos são coloridas pela matéria orgânica (águas pretas), apresentam teores de Al bem mais elevados do que os das águas que drenam as lateritas e teores de Si ligeiramente inferiores.

Tanto o processo de pedogênese do tipo lateritização, como podzolização permitem redistribuição de elementos ao longo do perfil do solo. Os sistemas lateríticos, por exemplo, caracterizam-se por apresentar perda de bases e parte da sílica no processo de alteração e pedogênese, e tendem a acumular Al e Fe, incorporados aos minerais de argila e aos óxidos e hidróxidos de Al e Fe, e elementos traços metálicos $(\mathrm{Zr}$, Th e Ti). $\mathrm{O} \mathrm{Ti}$, Th e $\mathrm{Zr}$ são elementos que ocorrem em minerais muito resistentes ao intemperismo no ambiente pedológico (HUTTON, 1977). Nos perfis lateríticos formados in situ, é normal encontrar teores mais elevados destes elementos no solo do que na alteração ou na rocha matriz. Entre esses elementos, o $\mathrm{Zr}$ pode ser considerado o menos solúvel e consequentemente menos móvel (CORNU et al., 1999). O Th em condições lateríticas apresenta mobilidade geoquímica baixa, entretanto em condições ácidas e na presença de ácidos húmicos, pode ser transportado em solução coloidal adsorvido em argilas e óxidos de Fe (DICKSON \& SCOTT, 1997) e colóides orgânicos (VIERS et al., 1997).

Os óxidos de titânio são considerados mais facilmente intemperizáveis nos solos do que o zircão. O titânio é liberado pelo intemperismo dos minerais primários como anatásio. Pesquisas realizadas nos últimos anos demonstraram, que em certos ambientes o Ti pode tornar-se instável e sofrer processos de dissolução (CORNU et al., 1999). Algumas evidências e indicações da mobilidade foram apresentadas por alguns autores: a presença de Ti na forma de gel e como constituinte de minerais secundários como as 
caulinitas (MALENGREAU et al.,1995); o intemperismo do rutilo e da ilmenita e a precipitação do Ti como anatásio (CORNU et al., 1999); concentrações menores do que as esperadas em balanços de massa de perfis lateríticos (LUCAS, 1989).

A distribuição dos elementos maiores e traços no solo além de auxiliarem na identificação dos processos maiores dominantes, em função dos elementos concentrados ou exportados ao longo da evolução dos perfis, também permitem interpretações sobre a natureza autóctone/alóctone dos materiais. As interpretações partem do princípio de que os elementos químicos possuem diferentes susceptibilidades ao transporte químico (solubilidades diferentes) e ao transporte físico (granulometrias diferentes). Neste trabalho, utilizando os resultados da análise química total dos principais constituintes dos solos procurou-se averiguar a redistribuição dos elementos durante a pedogenese num sistema de solo lateritico-podzolizado.

\section{MÉTODO}

\section{Caracterização da área de estudo}

A topossequencia escolhida situa-se na região da Alta Bacia do Rio Preto. Localiza-se no município de São Gonçalo do Rio Preto, dentro do Parque Estadual do Rio Preto, cerca de $30 \mathrm{Km}$ de Diamantina, região centro-norte do Estado de Minas Gerais (figura 1) .

Esta área está sobre rochas do Supergrupo Espinhaço, constituída por quartzitos, filitos e metaconglomerados com intercalações de metapelitos, xistos e intrusões de rochas metabásicas (ALMEIDA-ABREU \& RENGER, 2002). O relevo apresenta superfícies escalonadas, sub-horizontais e vertentes longas e de baixa declividade, interrompidas por vales fluviais encaixados e por cristas quartzíticas que podem apresentar aspecto ruiniforme. Com relação ao clima, a área de estudo enquadra-se no tipo Cwb, clima tropical de altitude segundo a classificação climática de KOOPEN (1948), que se caracteriza por apresentar invernos secos e verões amenos. Os solos predominantes são rasos, arenosos, pobres em nutrientes e ricos em ferro e alumínio trocáveis. 
Apresentam também grande acúmulo de substancias húmicas em função das baixas taxas de decomposição da matéria orgânica (BENITES, 2002).

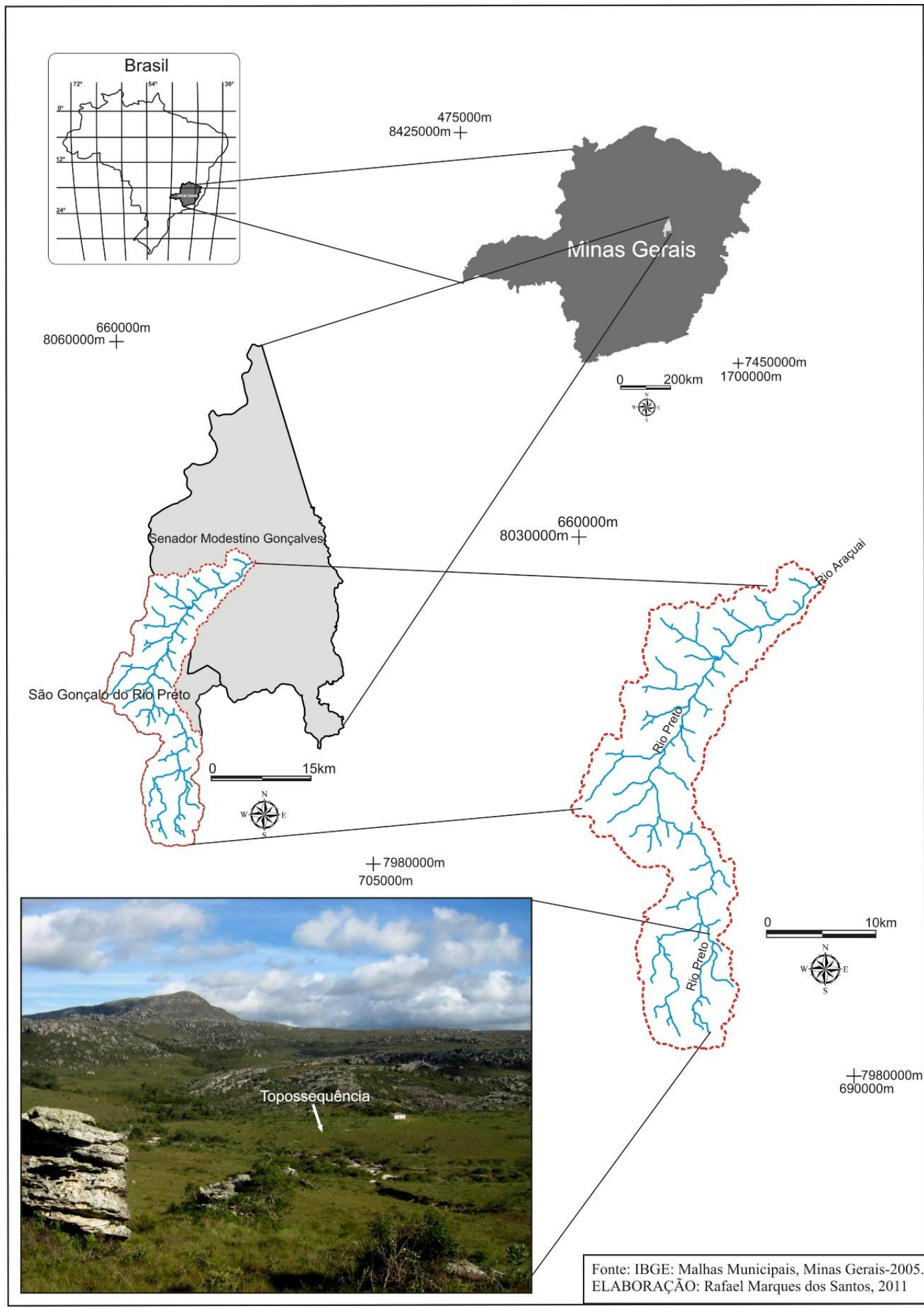

Figura 1: Localização da área de estudo

\section{Topografia da topossequencia e estudo dos materais}

O trabalho possui suas bases ancoradas no método da Análise Estrutural da Cobertura Pedológica proposto por BOULET et al., (1984) que baseia-se 
nos estudos dos diferentes tipos de organização dos solos nas dimensões bi e tridimensionais, desde a escala da paisagem, até a escala microscópica, em campo e em laboratório.

Para a escolha e implantação da topossequencia foram realizados estudos prévios da área com auxílio dos mapas de serviço. No campo seguiuse uma linha que "corta" perpendicularmente as curvas de nível, indo do topo em direção da base de uma vertente. Ao longo desse eixo realizou-se, primeiramente, o levantamento topográfico detalhado, com o auxilio do clinômetro e de uma trena. Em seguida procedeu-se ao estudo pedológico, efetuando-se as tradagens, que orientaram, posteriormente, a abertura das trincheiras. Essas últimas permitiram o estudo detalhado das transições laterais e a observação detalhada dos materiais.

Os minerais da fração argila foram determinados por infravermelho com Transformada de Fourier (FT-IR). As amostras foram moídas, misturadas com $\mathrm{KBr}$, homogeneizadas em almofariz de ágata e submetidas a pressões em prensa manual. Posteriormente foram submetidas a radiação na faixa do MIR (250 a 4000cm-1), utilizando-se um espectômetro Varian 640-IR, FT-IR. Os óxidos e hidróxidos de ferro foram determinados por Espectroscopia por Reflectância Difusa (DRS), utilizando-se um aparelho espectômetro Varian Cary 5E-US-VIS-NIR, e tiveram como referência a faixa da EPT (Transição de Par de Elétrons). Os picos de absorção registrados na faixa da EPT entre 485 e $499 \mathrm{~nm}$ foram atribuídos à goethita, enquanto os picos entre 521 e $565 \mathrm{~nm}$ referem-se à hematita.

A quantidade relativa de elementos maiores e em traços no solo foram determinados através da análise química total por Fluorescência de Raios-X (FRX). As análises foram realizadas no laboratório Actlabs, em Ancaster, Canadá. Os ganhos ou perdas relativas dos elementos (j) nos perfis estudados foram determinados pelo fator do balanço de massa segundo a equação proposta por CHADWICK et al., (1990):

$$
\mathrm{Tj}, \mathrm{w}=(\mathrm{Cj}, \mathrm{w} / \mathrm{Ci}, \mathrm{w}) /(\mathrm{Cj}, \mathrm{p} / \mathrm{Ci}, \mathrm{p})-1
$$

Essa equação corresponde à taxa de concentração do elemento químico que se deseja avaliar ( $(j)$ em relação ao elemento químico invariante ( $(l)$ em um 
material intemperizado considerado $(w)$ comparado ao conteúdo desses mesmos elementos no material de origem $(p)$, menos 1. A concentração desses elementos no material de origem $(p)$ é uma referência e, então, assimilado a uma constante. $O$ fator do balanço de massa menor que 1 referese à perda do elemento químico avaliado (j), enquanto o fator de balanço de massa superior a 1 revela ganho desse mesmo elemento. O elemento químico usado como invariante nesse estudo foi o zircão.

\section{RESULTADOS E DISCUSSÕES}

\section{Estrutura dos sistemas de solo}

As organizações pedológicas estão representadas bidimensionalmente na figura 2. Com aproximadamente $180 \mathrm{~m}$ de extensão total, a topossequência apresenta altitudes variáveis entre 1352 m a 1344 m, na montante e na jusante, respectivamente. De TR1 a TR6 a morfologia da encosta apresenta forma convexa; de TR6 em direção da jusante torna-se levemente côncava. Os horizontes estudados foram agrupados dentro de dois sistemas de solos, um localizado na montante e outro na jusante e estão distribuídos conforme suas características, em três compartimentos na topossequencia, denominados I, II e III.

Compreende o setor da montante da topossequência; é formado por um conjunto de horizontes de cor amarelo-avermelhada (anexo 1). 0 compartimento II engloba o trecho de TR4 até a TR9 (figura 2). Constitui-se num setor de transição na topossequência, com características tanto do compartimento I como do III. A distribuição dos horizontes nesse compartimento é bastante peculiar: seqüência de horizontes amareloavermelhados intercalados por horizontes fortemente impregnados por matéria orgânica (anexo 1). De TR9 prolongando-se até o final da topossequencia localiza-se o compartimento III (figura 2), compreendendo o setor de jusante. Representa um conjunto de horizontes fortemente impregnados por matéria orgânica intercalados por níveis eluviais descontínuos, sobrepostos a materiais grosseiros arredondados encontrados na base do perfil (anexo 1). 


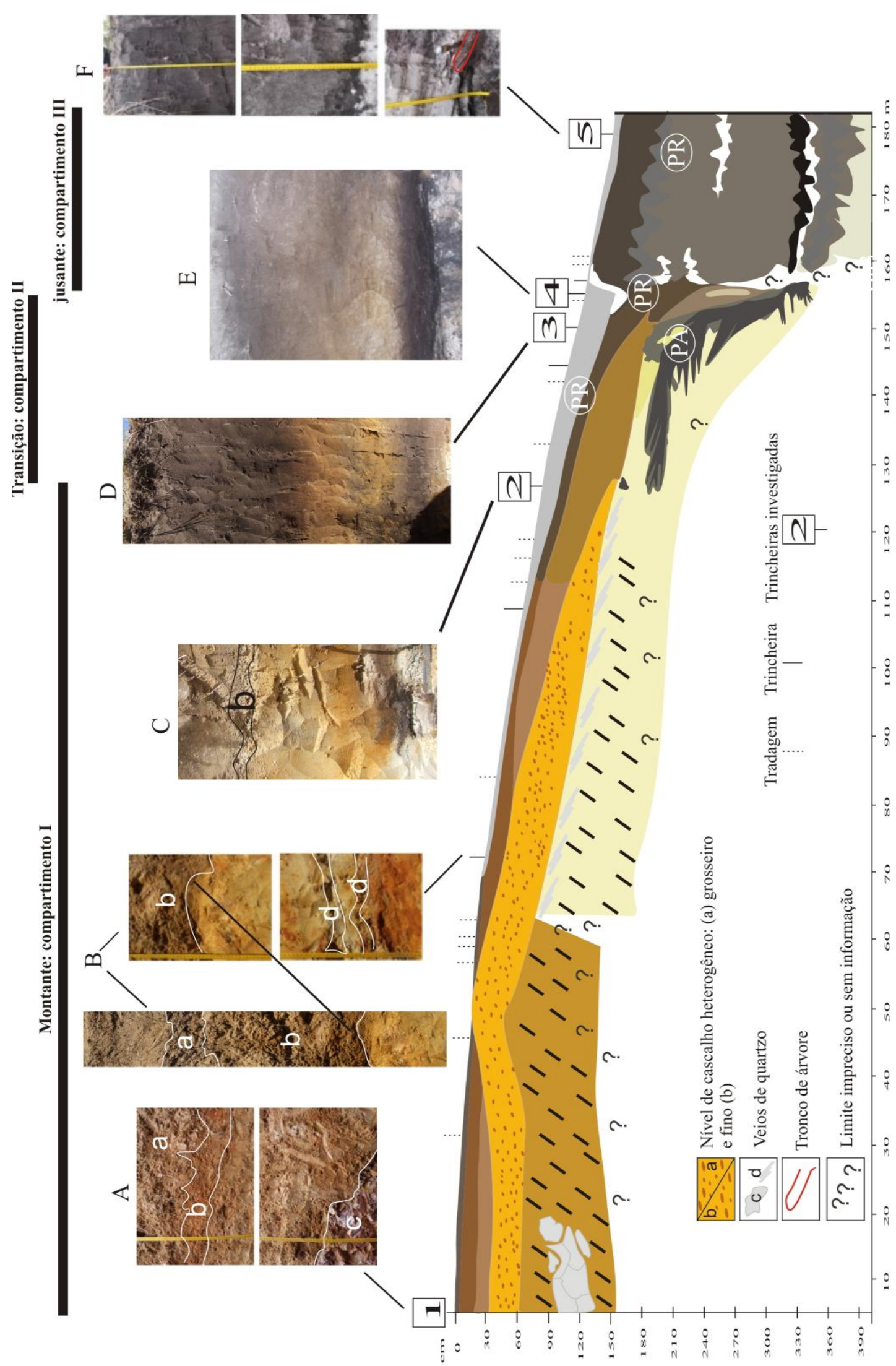

Figura 2: Organização dos sistemas de solo na topossequência. 


\section{A PEDOGÊNESE E A DISTRIBUIC̃̃̃O DOS ELEMENTOS MAIORES E TRAÇOS NUM SISTEMA DE SOLO LATERITICO-PODZOLIZADO NA ALTA BACIA DO RIO PRETO-MG}

\section{Legenda da figura toposseq.}

Domínio de Alteração

Sistema oxidante

IC' Alternância de filito e metarenito alterado com textura petrográfica

IIC Metarenito alterado com textura petrográfica

Sistema hidromórfico

IIC Metarenito alterado com textura petrográfica; hidromorfia

IIIC/E Sedimentos recentes (areias, grânulos orgânicos, cascalhos, tronco); hidromorfia

Sistema hidromórfico/Podzolizado

Bruno acinzentado a preto

Bh/IIC (10YR3/1;2/1); Mo penetra entre as bandas do metarenito alterado e envolvendo os grãos de quartzo da matriz

\section{Domínio Podzolizado}

Horizontes espódicos

$\mathrm{Bh} 1$ Empretecido (10YR 4/3) com domínios amarelos(10YR7/6); arenoso; Mo envolvendo os grãos de quartzo; maciço, poroso

runo empretecido (7.5YR3/2) a bruno; arenoso; maciço/granular; poroso; com raizes; Mo impregna o horizonte envolvendo os grãos de quartzo.

Bhs Bruno empretecido a bruno acinzentado (10YR3/3; 3/1; 4/2); Mo em grãos e envolvendo o quartzo; arenoso; maciço/granular; poroso; com raízes

Brunado (10YR5/3), arenoso; maciço/ grãos soltos; grânulos de Mo; poroso

Bh2 Preto (10YR 2/1); Mo em grãos e envolvendo o quartzo; arenoso; maciço/grãos soltos; muito poroso; figuras de eluviação (10YR7/2)

Bh3 Cinza brunado a preto (10YR5/2; 2/1); Mo em grânulos; areia fina; grãos soltos; poroso; figuras de eluviação (10YR7/1) arenoso; grãos soltos; Mo em grãos e envolvendo o quartzo,muito poroso

Bhs/E Cinza claro (10YR4/2, 3/1); arenoso; grãos soltos; Mo em grãos e envolvendo o quartzo, muito poroso
Bh/E Empretecido (7.5YR7/0);
Domínio Laterítico

Horizontes lateríticos

A11 Bruno (10YR5/3); arenoso; granular arenoso; maciço/granular com grãos soltos.

A/B Bruno amarelado (10YR5/6); arenoso; maciço/granular; canais preenchidos por Mo

B1/Bs Brunado (5YR5/6; 7,5YR5/6); domínios com Mo (10YR4/2); pontuações (2.5YR4.5/3); arenoso; maciço/granular;

B/IIC Amarelo (10YR7/6; 7/8); manchas empretecidas; arenoso; maciço
A 12 Bruno amarelado (10YR5/6 a 5/4);

\section{Horizontes álbicos}

AE Branco a cinza escuro (10YR8/2;4/1), (Ae1) bruno claro a acinzentado (10YR6/3; 7/1), (Ae2); acinzentado (10YR6/1), (Ae3); arenosos, grãos soltos de quartzo lavado, e grânulos de Mo; muito poroso, com raízes

E Cinza claro e bruno acinzentado (10YR7/1; 5/2); muito arenoso (areia fina, perfil 4, areia grossa, perfil 5); grãos soltos de quartzo lavado; e grânulos de Mo; muito poroso com raízes 


\section{Distribuição dos elementos maiores e traços no solo}

Nos gráficos apresentados nas figuras 3, 7, 9 e 10 a linha tracejada representa o $\mathrm{Zr}$, que é o fator 1 do balanço; os pontos que aparecem à direita de 1 indicam ganho do elemento considerado, e os da esquerda de 1, perda.

A distribuição de Fe frente ao fator 1 mostra que há ganho em ferro em três horizontes da topossequência, na superfície e em profundidade. Na TR2 correspondem aos horizontes A12 e IIC2.

a)

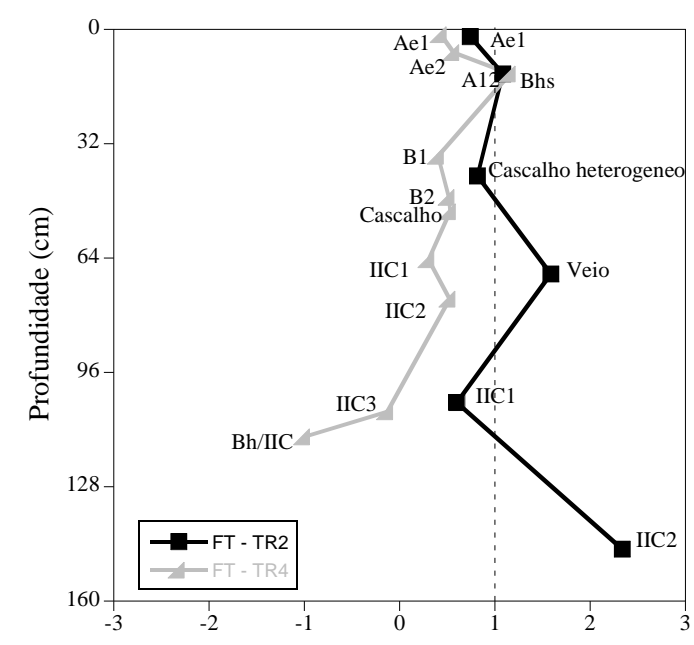

Fator do Balanço de Massa b)

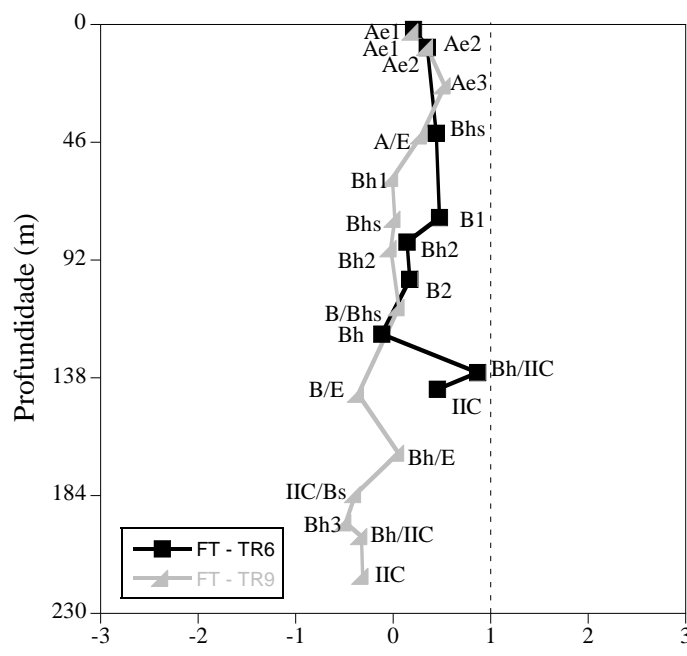

Fator do Balanço de Massa

Figura 3: Balanço de massa para $\mathrm{FE}_{2} \mathrm{O}_{3}$, (a) TR2 e TR4 e (b) TR6 e TR9

Goethita, traços de hematita, caulinita e gibsita (4a e 4b) são os minerais presentes nestes horizontes, entretanto, apenas, a existência dos óxidos de Fe não explicam esse ganho, uma vez que nos demais horizontes desse solo eles também existem.

A primeira acumulação de ferro está em A12, horizonte imediatamente abaixo de um Ae2, enquanto na base a acumulação ocorre no IIC2, imediatamente abaixo do nível de cascalho, horizonte este, extremamente poroso e mais rico em matéria orgânica (MO) (figura 6a). A acumulação da $\mathrm{MO}$ em horizontes não só superficiais, avança a idéia, que já em TR2, ela pode ser dissolvida e mobilizada, possibilitando a formação de complexos organo-metálicos que vão se acumular nos horizontes menos porosos. 
a)

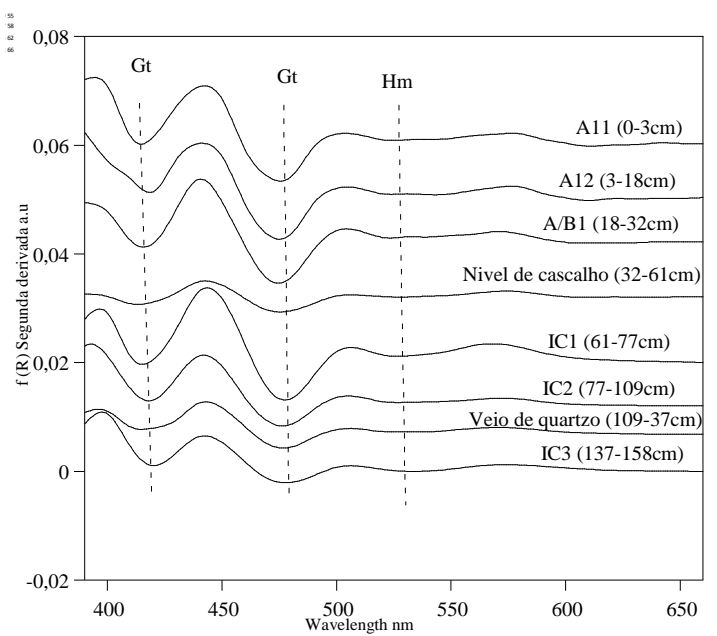

b)

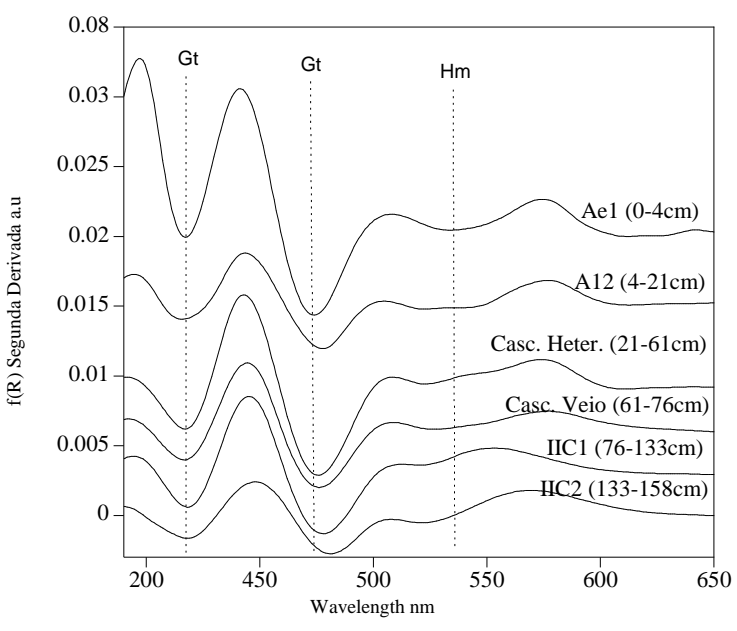

Figura 4: Espectros da segunda derivada da função de reemissão f $R$ (DRS) das bandas (mínimas) de hematita e goethita, (a)TR1 (b) TR2

Embora a curva do balanço em TR4, apresente uma variação irregular denotando, valores mais altos intercalados por mais baixos, apenas um horizonte apresenta ganho de ferro, é o Bhs (figura 3a). Nesse se acumulam mais ferro e mais MO. Essa acumulação informa sobre a dissolução e mobilidade da MO, que pode complexar o ferro. Esse padrão segue o da distribuição de $\mathrm{MO}$, como para TR2; há a associação entre maiores teores de MO e ferro (figura 6b). Entretanto, a base do perfil TR4, apresenta perda de ferro, o que não ocorre em TR2. Essa organização demonstra que de TR2 para a direção de TR4 os processos de dissolução e mobilidade da $\mathrm{MO}$ e do ferro estão mais ativos. Portanto, o sistema laterítico de alteração e de pedogênese já começa a ser superimposto pela podzolização, desde o topo da vertente enquanto a hidromorfia progride na base do perfil TR4. E está, em TR2, ligado à acumulação de matéria orgânica de superfície. A figura 6b, revela que há uma diminuição do conteúdo de MO no horizonte sobreposto ao Bhs.

Os perfis TR6 e TR9 são, fortemente, deplecionados em ferro (figura 3b), embora a mineralogia revele goethita e traços de hematita em TR6 (figura 5b).

As quantidades de MO (figura 6c, d) nos horizontes dos dois perfis são globalmente maiores do que em TR2 e em TR4, mas, como para estes perfis precedentes, nos horizontes onde os conteúdos de MO são altos, corresponde a maiores teores de Fe (figura 6b). Embora os dois perfis percam ferro, este concentra-se na parte do topo e decai na base, dos perfis. A distribuição desse elemento em ambos os perfis, segue a dinâmica da podzolização. 
a)

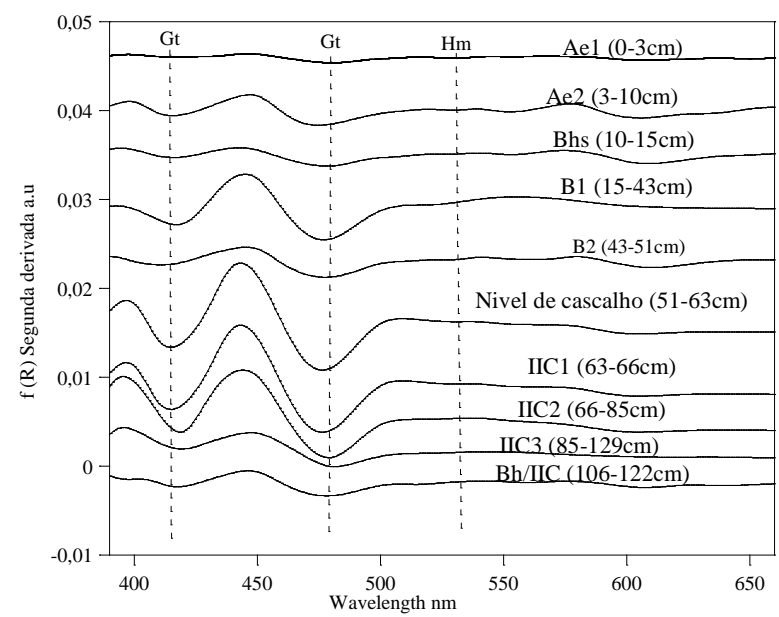

b)

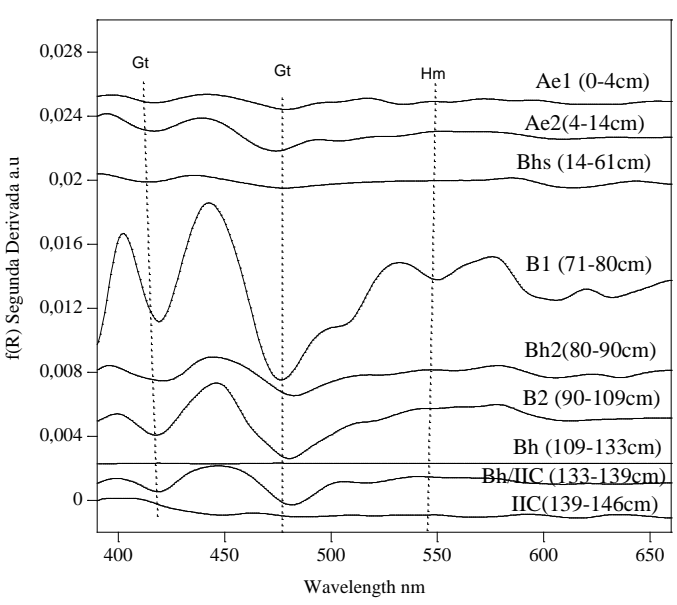

Figura 5: Espectros da segunda derivada da função de reemissão f $R$ (DRS) das bandas (mínimas) de hematita e goethita, (a)TR4, (b)TR6

a)

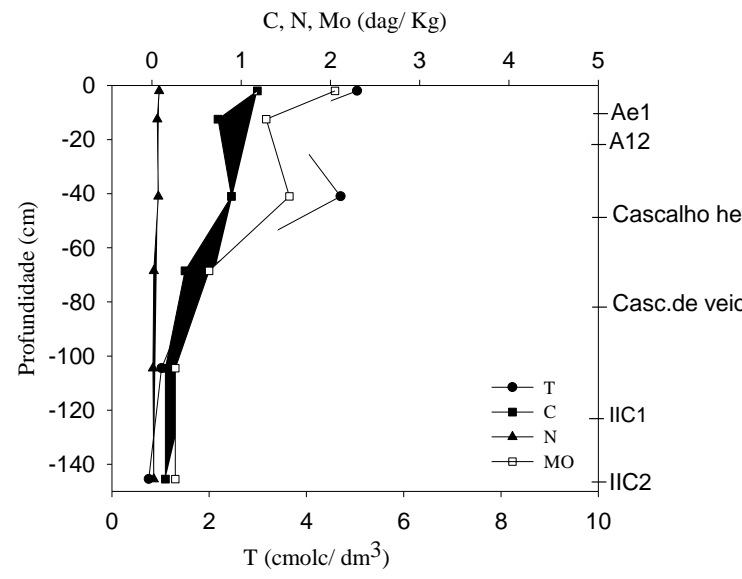

b)

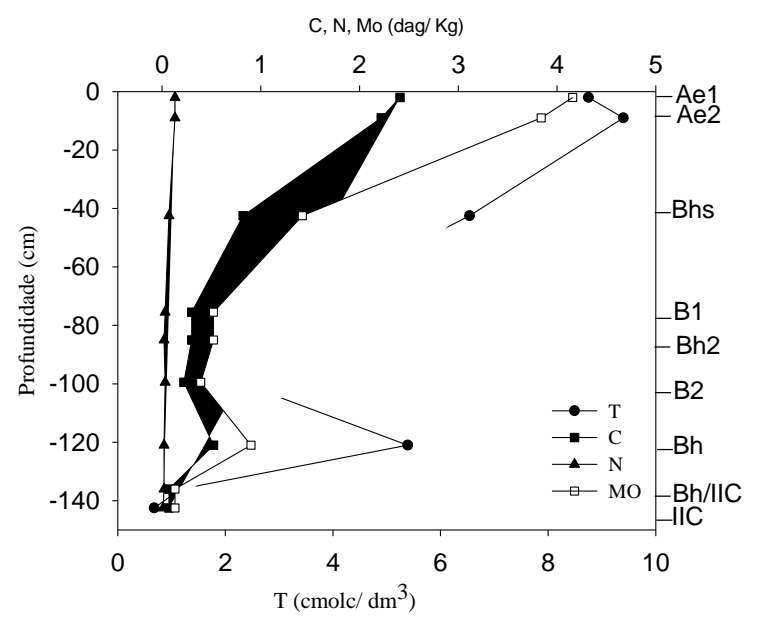

b)

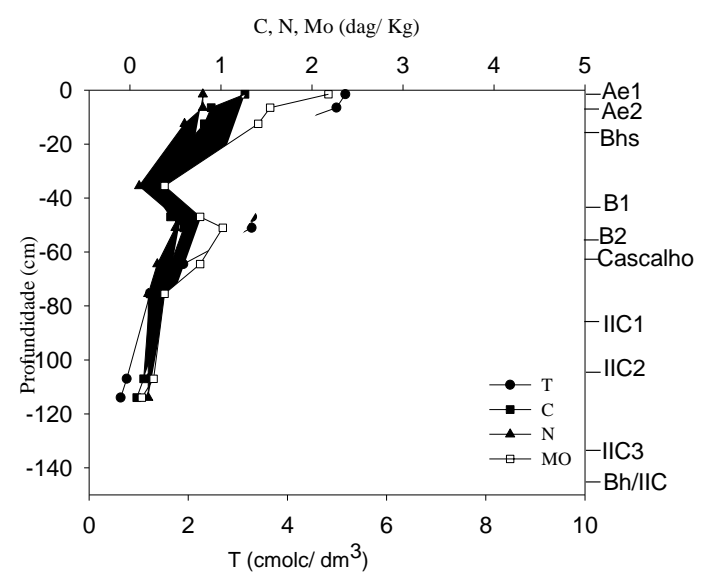

d)

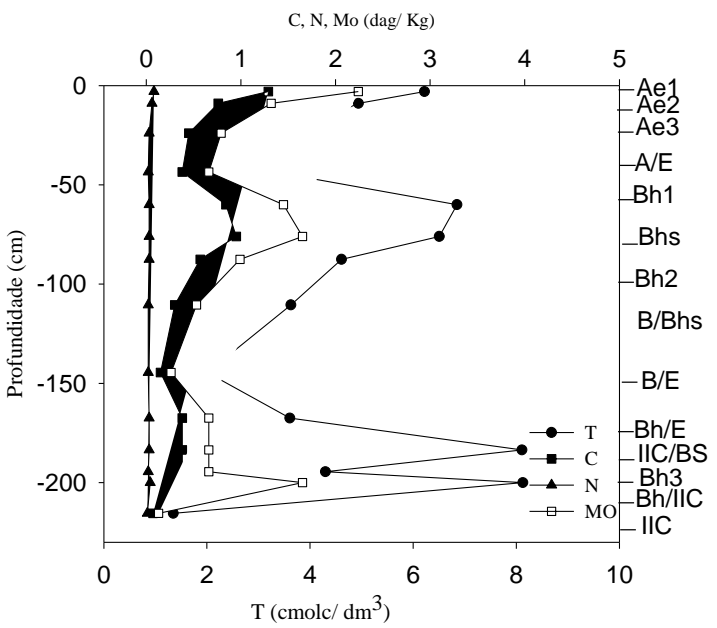

Figura 6: Distribuição de MO, C, N e T para (a) TR2, (b)TR4, (c)TR6 e (d)TR9 
A depleção de ferro aumenta para a direção de jusante, de TR2 até TR9. Mas TR2 mantém ganho, maior, de ferro na base do perfil. Essa diferenciação entre TR2 e os demais perfis, revela fortemente uma mudança no sistema geoquímico. De fato, o sistema de alteração e pedogênese na montante (TR2), é oxidante, enquanto que indo em direção de jusante ele se torna hidromórfico, na base dos perfis (figura 2). Existe mais ferro nos horizontes superiores de TR6 e TR9, do que nos horizontes da base desses mesmos perfis. Assim, pode-se afirmar que existe uma contraposição entre os horizontes da base e os do topo de TR6 e TR9, o que aponta para uma diferença no sistema de alteração e pedogênese entre o topo e a base de ambos os perfis. No topo o ambiente é oxidante. Isso não explica a perda de ferro do topo, enquanto a hidromorfia da base é responsável pela depleção deste elemento neste nível.

Os espectros DRS (figura 5b), mostraram que para TR6 as goethitas tornam-se cada vez mais aluminosas para a direção do topo. A sucessão de transformação de goethita em goethita aluminosa, a partir da dissolução das gibsitas, explica a perda de ferro, também, nos horizontes superiores. Entretanto, a diferença de conteúdos entre base e topo sugere que a hidromorfia é mais eficiente para a remoção do ferro da base desses dois perfis. Assim conclui-se que o sistema de alteração podzolizante permite a redistribuição do ferro no perfil, enquanto o sistema hidromórfico e a transformação mineralógica respondem pela depleção do ferro.

A figura 7 mostra que tem perda em Al no topo e ganho, apenas, no veio e nos horizontes da base de TR2 e de TR4.

A mineralogia FT-IR (figura $8 a$ e $8 b$ ) revelou que domina na base de TR2, como em TR4, caulinita bem cristalizada e traços de gibsita e que na direção do topo, tanto caulinita como gibsita diminuem em quantidade.

Essa transformação mineralógica explica a depleção de Al no topo dos perfis, relacionada, como para o ferro, à dinâmica da $\mathrm{MO}$, em ambiente podzolizante, mas não explica a intensidade dos picos de caulinita e a presença de gibsita na base. Em TR2 a depleção é progressiva enquanto em TR4 a configuração da curva é irregular (figura 7a e b). Entretanto, nesse último perfil, o padrão da curva mostra a intercalação entre maiores e menores teores de Al, que segue o mesmo padrão de curva da MO (figura 6b). Essa comparação entre as curvas mostra a relação entre os conteúdos de MO e os de Al, explicando a configuração da curva em TR4. 
a)

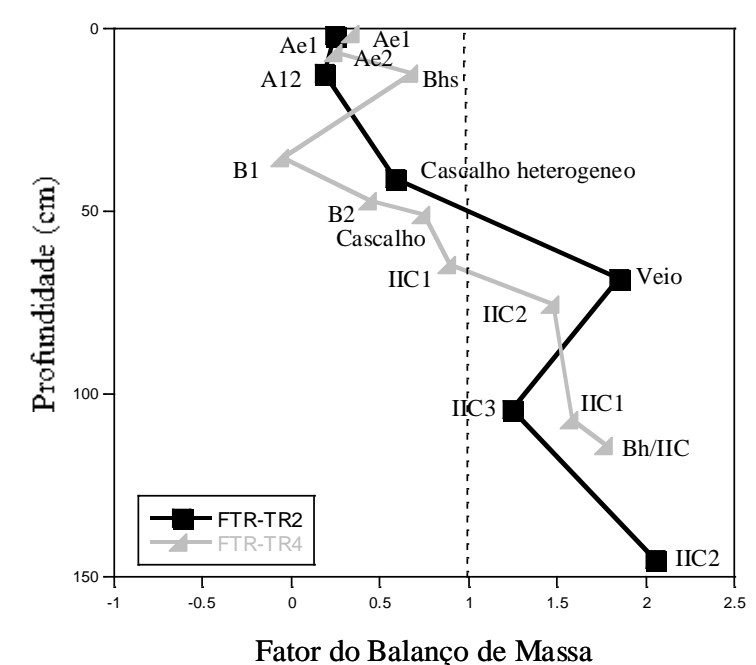

b)

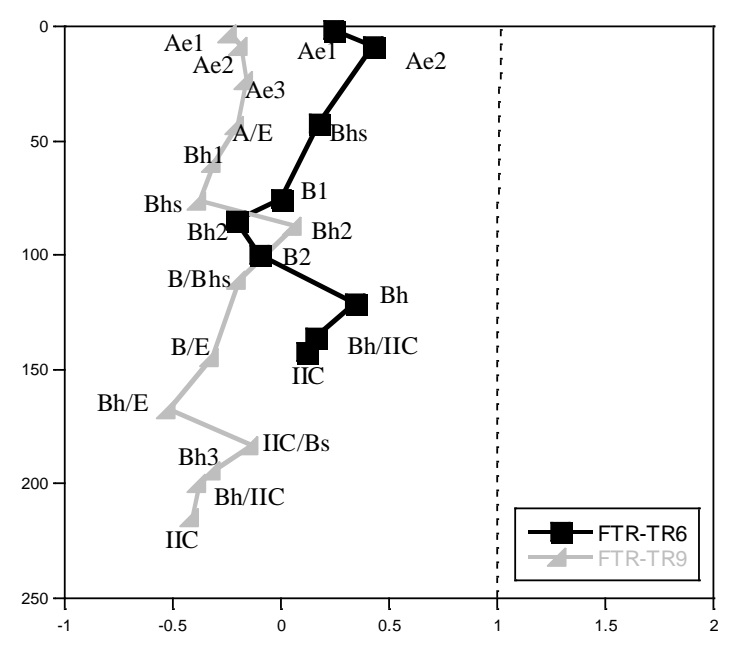

(a) TR2 e TR4 e (b) TR6 e TR9 a)

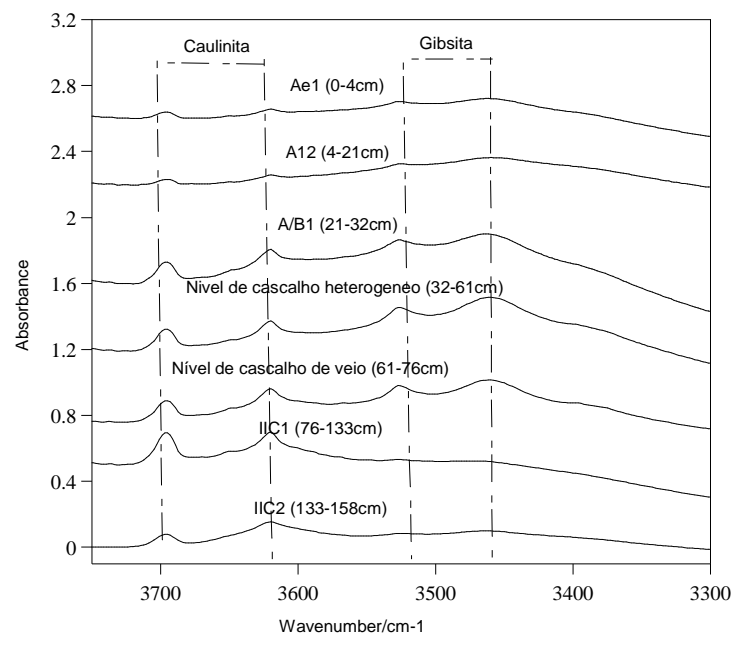

b)

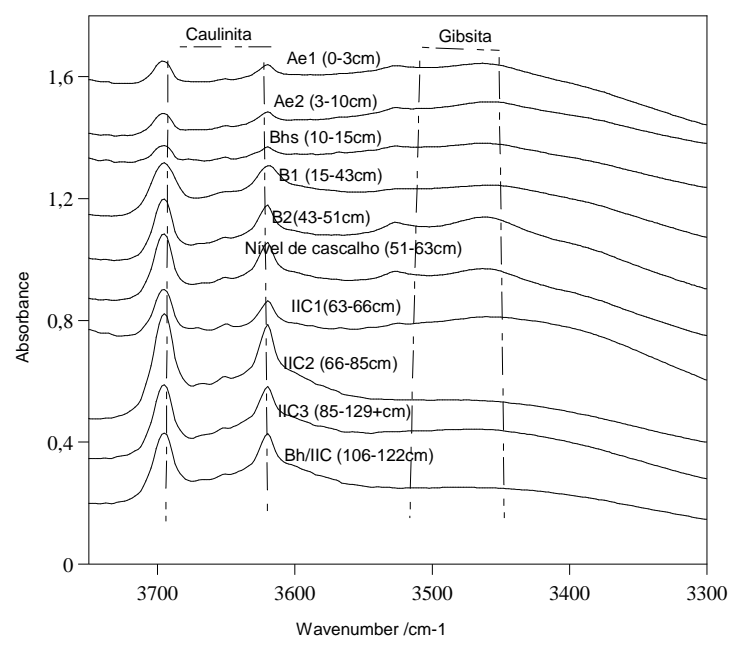

Figura 8: Espectros FT-IR (a) TR2 , (b)TR4

Essa distribuição frente à $\mathrm{MO}$ revela que a do $\mathrm{Al}$, como para o $\mathrm{Fe}$, é reflexo da dinâmica imposta pela podzolização. Portanto, as perdas e a distribuição de Al no topo dos perfis TR2 e TR4 e na base de TR4, tem origem na podzolização, enquanto na base, a alteração das muscovitas em TR2, enriquece este nível em Al. Todo o perfil TR6 e TR9 é deplecionado em Al. Em ambos os perfis os picos de concentração de $\mathrm{Al}$ correspondem a teores altos de $\mathrm{MO}$ (figuras $6 \mathrm{c}$ e $6 \mathrm{~d}$ ), revelando a complexação do Al pela MO. De montante indo em direção da jusante (TR2 à 
TR9), a depleção de Al aumenta reafirmando que a podzolização está mais desenvolvida na direção de jusante, sobretudo, em TR9.

Na TR2 não existe perda de Ti (figura 9a), viu-se que o sistema de alteração é lateritizante e que a distribuição de Ti está coerente com este tipo de alteração e pedogênese, isto é, Ti acumula-se residualmente a partir da alteração dos minerais, embora uma perda progressiva já é percebida para a direção do topo do perfil. Isso confirma que a podzolização já está em processo neste perfil; a perda de titânio, portanto, pode estar ocorrendo, seja por dissolução ou por fracionamento físico decorrente da abertura da porosidade, ambos os motivos, reflexo da própria podzolização.

a)

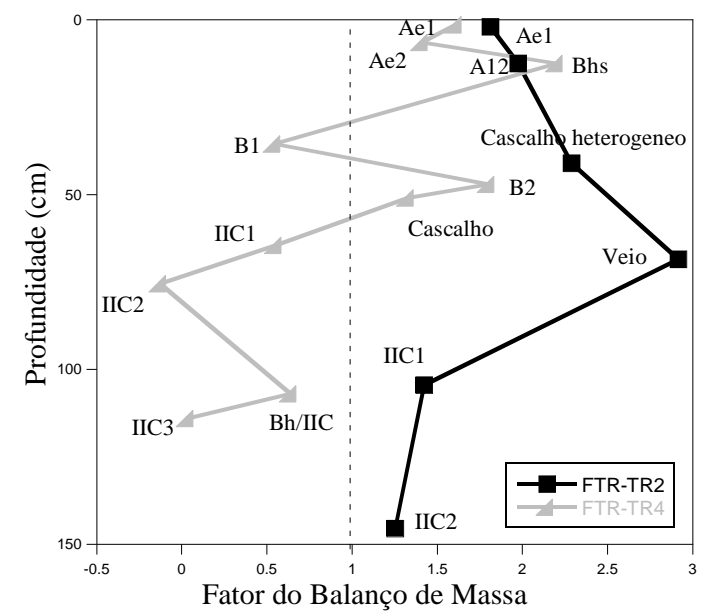

b)

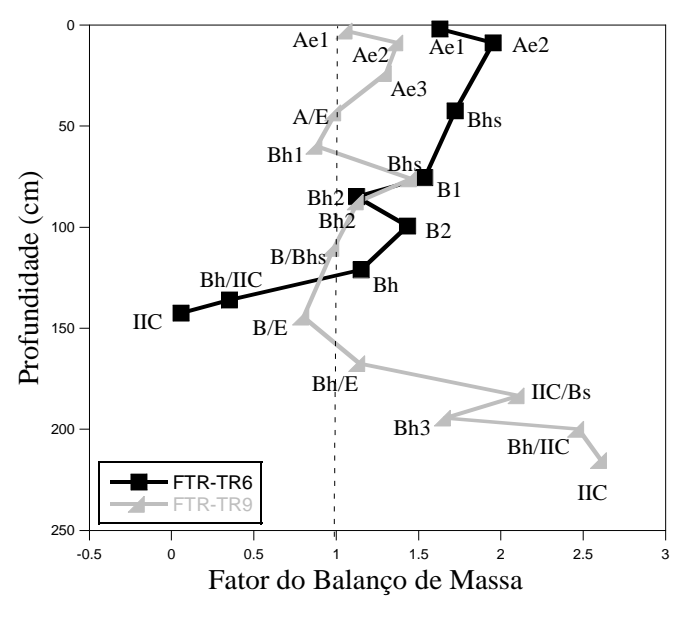

Figura 9: Balanço de massa para $\mathrm{TiO}_{2}(\mathrm{a}) \mathrm{TR} 2$ e TR4 e (b) TR6 e TR9

$\mathrm{Na}$ TR4 a distribuição do Ti envolve níveis de perda e de ganho (figura 9a). Entre 40 a $60 \mathrm{~cm}$ de profundidade no nível de cascalho de veio, o ganho pode ser atribuído, em parte, à alteração e fragmentação dos minerais primários aí presentes, viu-se que os quartzos e as muscovitas, estão abundantemente incrustados por mineral de titânio (titanita) o que explica parte do ganho neste nível. No topo, o Ti concentra no Bhs, indicando como para o ferro, uma migração do Ti, na forma de complexo organo-metálico, a partir do horizonte do topo para o Bhs. Da montante para a direção da jusante (TR2 à TR9) os perfis tornam-se mais deplecionados em Ti (figura 9a e b). Entretanto, em TR6 há ganho de Ti, maior no topo, e em TR9, na base do perfil. $O$ fracionamento físico e químico desse elemento, ligado com as 
transferências físicas, através do alargamento da porosidade, e com a dissolução, capacidade de complexação e mobilidade da $\mathrm{MO}$, explicam a distribuição desse elemento, as perdas e ganhos, em ambos os perfis.

As figuras $10 \mathrm{a}$ e b mostram perda de tório em todos os perfis da topossequência. De montante, para a direção jusante, essa perda é maior. A análise sobre o fracionamento referenda a perda na direção de jusante e esclarece a configuração da distribuição desse elemento nos perfis: na jusante todo o perfil TR9 é a fonte de Th complexado pela MO, que vai alimentar a base dos perfis TR4 e TR6, da montante.

a)

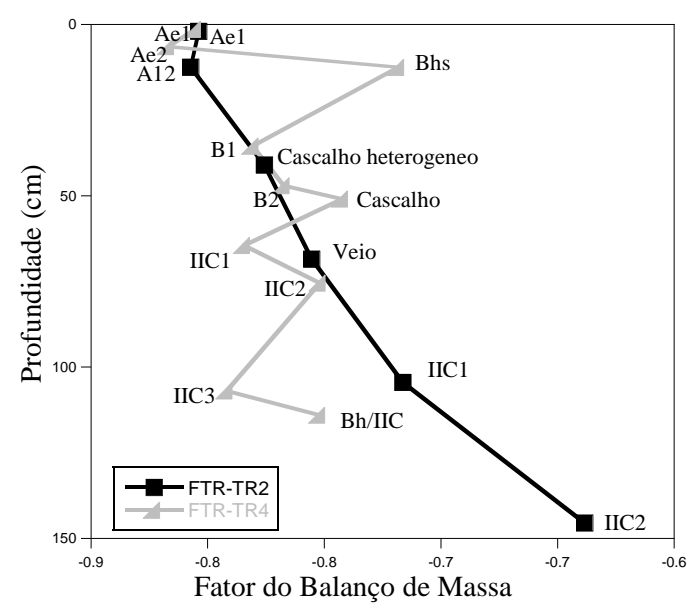

b)

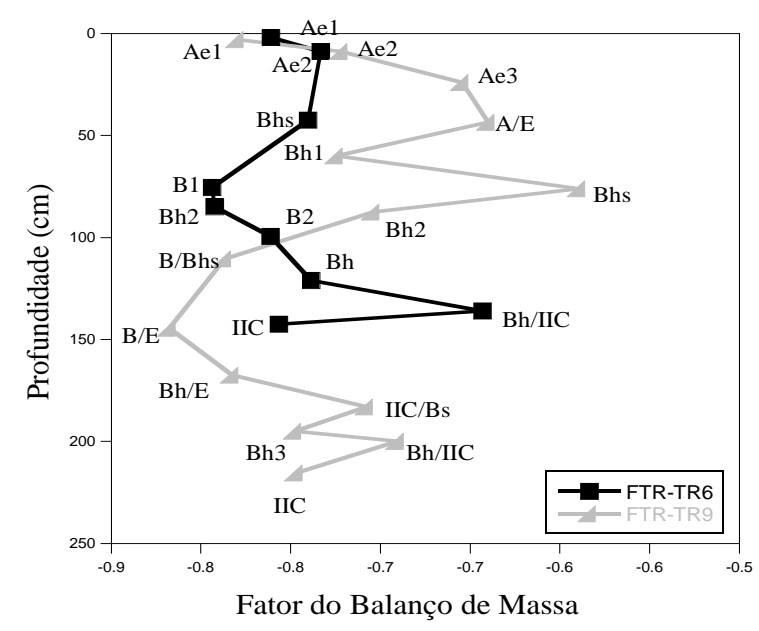

Figura 10: Balanço de massa para Th, (a) TR2 e TR4 e (b) TR6 e TR9

Através da análise dos gráficos da função transporte, pode-se observar que existe uma seqüência de perda dos elementos traços metálicos: Ti, mais do que $\mathrm{Al}$ e Fe e mais do que $\mathrm{Zr}$.

\section{CONCLUSÕES}

Os resultados comprovam que os processos de lateritização e podzolização apresentam influência direta na redistribuição de elementos ao longo dos perfis estudados. Pode-se observar atráves das figuras que a depleção dos elementos 
aumenta em direção à jusante da topossequencia, de TR2 a TR9. Essa tendência é reflexo da dinâmica imposta pela podzolização.

Os ganhos de Ti observados em TR2 estao associados ao processo de lateritização, portanto a distribuição de Ti está coerente com este tipo de alteração e pedogênese, isto é, Ti acumula-se residualmente a partir da alteração dos minerais, embora uma perda progressiva já é percebida para a direção do topo do perfil. Isso confirma que a podzolização já está em processo em direção a montante do perfil.

\section{Referências}

ALMEIDA-ABREU P. A. A; RENGER, F. E. Serra do Espinhaço Meridional: um orógeno de colisão do Mesoproterozoico. Revista Brasileira de Geociências, 31, 2002.

BENITES, V. M. Caracterização de solos e de substâncias húmicas em áreas de vegetação rupestre de altitude. Dissertação - (Doutorado em Solos e Nutrição de Plantas) - Universidade Federal de Viçosa, Viçosa, 2002.

BRAVARD, S; RIGHI, D. Podzol in Amazonia. Catena, 17. 1990.

BOULET, R.; CHAUVEL, R.; LUCAS Y. Les systemes de transformation enpedologie. Livre Jubilaire du Cinquantenaire - Association Française pour I'Etude du Sol, Maugein - Lachaise, Malemort. 1984.

BUOL, S. W.; HOLE, F. D.; Mc CRACKEN, R. J. Soil genesis and classification. Ames: ISUP. 1997.

CORNU, S; LUCAS, Y; LEBON, E; AMBROSI, J. P; LUIZÃO, F; ROUILLER, J; BONNAY, M; NEAL, C. Evidence of titaninum mobility in soil profiles, Manaus, central Amazonia. Geoderma, 91, 1999.

DELVIGNE, J. Pédogenèse en zone tropicale: La formation des mineraux secondaires em milieu ferrallitique. Paris, 1965. (Mémoires ORSTOM, 13).

DICKSON, B. L.; SCOTT, K. M. Interpretation of aerial gammaray surveys adding the geochemical factors. AGSO Journal of Australian Geology \& Geophysics, $17,1997$.

FRITZ, B; TARDY,Y. Etude thermodynamique du système gibbsite, quartz, kaolinite, gaz carbonique.Application la genèse des Podzols et des bauBxites. Sci. Géol. Bull. 26, 1974.

HUTTON, J. T. Titanium and zirconium minerals. In: DIXON, J. B \& WEED, S. B. Minerals in soil environment. Madison: Soil Science Society of América.1997. 
KÖPPEN, W. Climatologia: con un estudio de los climas de la tierra. Fondo de Cultura Econômica. México. 479p, 1948.

LUCAS, Y. Systémes pédologiques en Amazonie brésilienne. Équilibres, déséquilibres et transformations. 1989. Tese (Doutorado). Universidade de Poitiers, Paris, 1989.

LUCAS, Y; NAHON, D; CORNU, S; EYROLLE, F. Genese et fonctionnemet des sols en milieu equatorial. C. R. Academic des Science de Paris. 1996.

LUNDSTRÖM, U. S.; VAN BREEMEN, N. \& BAIN, D. The Podzolization process: a review. Geoderma, 94, 2000.

MALENGREAU, N; MULLER, J. P; CALAS, G. Spectroscopic approach for investigating the status and mobility of $\mathrm{Ti}$ in kaolonitic materials. Clays and clay minerals, 43, 1995.

MELFI, A. J; PEDRO, G. Estudo Geoquímico dos solos e formações superficiais do Brasil. Parte 1: Caracterização e repartição dos principais tipos de evolução pedogeoquímica. Revista Brasileira de Geociências, 7, 1977.

MELFI, A. J. \& PEDRO, G. Estudo geoquímico dos solos e formações superficiais do Brasil. Parte 2: Considerações sobre os mecanismos geoquímicos envolvidos na alteração superficial e sua repartição no Brasil. Revista Brasileira de Geociências, 8, 1978.

PETERSEN, L. The Podzol concept. In: Buurman, P. Podzols. New York: Van Nostrand Reinhold Company Inc. 1984.

TOLEDO, M. C. M.; OLIVEIRA, S. M. B.; MELFI, A. J. Intemperismo e Formação do Solo. In: TEIXEIRA, W. et al (Org). Decifrando a Terra. São Paulo: Oficina de Textos, Cap 8, 2000.

VIERS, J; DUPRE, B; BRAUN, J. J; DEBERT, S; ANGELETTI, B; GOUPAYOU, J. N; MICHARD, A. Major and trace element abundances and strontium isotopes in the Nyong Basin Rivers (Cameroon): Constraints on chemical weathering process and elements transport mechanisms in humid tropical environments. Chem Geol, 169, 1997. 
Anexo 1: Descrição dos perfis de solo da topossequência

\section{TRINCHEIRA 8}

\section{0-2cm: Horizonte Ae1}

Cor cinza clara (grãos soltos de areia branca, 10YR8/1 e grânulos de matéria orgânica, 10YR4/1); arenoso; muito poroso; raízes finas.

\section{2-11cm: Horizonte Ae2}

Acinzentado (10YR7/1); arenoso, aspecto maciço que se desfaz em grãos soltos de areia branca (10YR8/1) e grânulos muito pequenos de matéria orgânica (10YR4/1); ocorrência de pequenos domínios de material brunado (10YR4/3); poroso. Limite nítido com o horizonte superior; raízes finas.

\section{1-51cm: Horizonte Bh1}

Cinza escura empretecida (10YR2/1), com pequenas pontuações de areia lavada branca (10YR 8/1) e material bruno empretecido (10YR4/3); arenoso; maciço que desfaz em grãos soltos; poroso. Limite nítido com o horizonte superior; raízes finas.

\section{1-73 cm: Horizonte Bh/E}

Acinzentado empretecido (10YR3/1); arenoso; maciço que desfaz em grãos soltos; poroso com canais preenchidos por matéria orgânica. Transição gradual com 0 horizonte superior; raízes finas e grossas.

\section{3-128 cm: Horizonte Bh/Bhs}

Brunado (10YR5/3); arenoso (areia fina); maciço que desfaz em grãos soltos e grânulos de matéria orgânica, alguns grânulos de até $1 \mathrm{~cm}$. Limite vertical nítido e interpenetrado com o horizonte $E$ lateral e Transição gradual com o horizonte superior; poucas raízes.

\section{0-114 cm: Horizonte E (descontínuo na trincheira)}

Esbranquiçado brunado (10YR6/3), muito arenoso; grãos soltos; muito poroso. Transição gradual com o horizonte superior; poucas raízes.

\section{8-146 cm: Horizonte Bh1}

Preto (10YR2/1) com pequenos canais arenosos brancos (10YR7/1) e pequenos grânulos bruno escuro (10YR3/4), arenoso (areia muito fina); maciço que desfaz em grãos soltos; poroso. Limite nítido e interpenetrado com o horizonte superior; poucas raízes finas. 


\section{6-150 cm: Horizonte E (descontínuo na trincheira)}

Esbranquiçado (10YR7/1) com domínios empretecidos (10YR3/1); muito arenoso; grãos soltos com grânulos de matéria orgânica; muito poroso. Limite nítido, interpenetrado com o horizonte superior.

\section{0-158 cm: Horizonte Bh2}

Preto (10YR2/1) com distribuição da matéria orgânica de maneira contínua; arenoso; maciço que desfaz em grãos soltos; poroso com pequenos canais com auréola esbranquiçada arenosa (10YR7/2). Limite nítido e interpenetrado com o horizonte superior; poucas raízes finas.

\section{8-183 cm: Horizonte Bh/E}

Empretecido (10YR3/1); grãos soltos de areia branca (10YR8/1) e grânulos de matéria orgânica (10YR3/1); arenoso (areia fina), maciço que desfaz em grãos soltos; muito poroso. Limite nítido e interpenetrado com o horizonte superior.

\section{3-189 cm: Horizonte Bh3}

Preto (10YR2/1) com distribuição da matéria orgânica de maneira contínua; arenoso; maciço que desfaz em grãos soltos; muito poroso com canais com auréola esbranquiçada arenosa (10YR7/2). Transição rápida com o horizonte superior.

\section{9-268 +cm: Horizonte IIIC/E}

Branco (10 YR 7/1) com bandas pretas a brunadas (10YR3/4); muito arenoso (areia grossa); estrutura bandada plano-paralela, menos nítida no topo do horizonte e mais nítida em direção da sua base, desfaz em grãos soltos; muito poroso. As bandas arenosas são intercaladas por bandas mais orgânicas pretas a brunadas, em grânulos. Tais bandas (arenosas e orgânicas) são cortadas discordantemente pelos festões empretecidos do horizonte superior e por volumes alongados, também, empretecidos (10YR2/1). Em $268 \mathrm{~cm}$, tronco de madeira dispõe-se de forma horizontal. Abaixo do tronco seixos rolados quartzosos tem diâmetro de até $5 \mathrm{~cm}$. Limite nítido, interdigitado, com o horizonte superior.

\section{TRINCHEIRA 7}

\section{0-2 cm: Horizonte Ae1}

Branco (10YR8/2); arenoso (areia fina); grãos soltos e grânulos de matéria orgânica; muito poroso; muitas raízes. 


\section{2-10 cm: Horizonte A/E}

Bruno acinzentado (10YR5/2); arenoso; grãos soltos de areia lavada e grânulos de matéria orgânica; poroso com canais preenchidos por material orgânico (10YR6/2). Limite nítido com o horizonte superior.

\section{0-36 cm: Horizonte Bh1}

Bruno acinzentado empretecido (10YR3/2) com distribuição da matéria orgânica de maneira contínua; arenoso; maciço que desfaz em granular; poroso. Limite nítido com o horizonte superior; poucas raízes.

\section{6-66 cm: Horizonte Bh/E}

Cor heterogênea, bruno acinzentada empretecida (10YR4/2) dominante e bruno acinzentada (10YR5/2). Arenoso; granular e grãos soltos; muito poroso. Transição gradual com o horizonte superior.

\section{6-72 cm: Horizonte E1}

Cor heterogênea, variando de cinza clara (10YR7/1), distribuída de forma irregular e descontínua no horizonte, a bruna acinzentada (10YR5/2). Arenoso; grãos soltos e grânulos de matéria orgânica de cor (10 YR 3/2); muito poroso. Limite nítido e interpenetrado com o horizonte superior.

\section{2-106 cm: Horizonte Bhs}

Bruno acinzentado empretecido (10YR4/2), com matéria orgânica distribuída de maneira contínua; arenoso; maciço que desfaz em granular; poroso. Limite nítido interpenetrado com o horizonte superior.

\section{6-117 cm: Horizonte E2 (descontínuo na trincheira)}

Cinza claro (10YR7/1); muito arenoso (areia grosseira lavada); grãos soltos com alguns grânulos de matéria orgânica; poroso. Limite nítido e interpenetrado com o horizonte superior.

\section{7-149 cm: Horizonte Bhs}

Bruno empretecido (10YR3/3), com algumas pontuações arredondadas vermelhas (2,5YR4/8), e Cinza muito empretecido (10YR3/1) com matéria orgânica distribuída de maneira contínua e com algumas pontuações de areia lavada; arenoso; maciço que desfaz em granular; muito poroso. Limite nítido e interpenetrado com o horizonte superior.

\section{9-165 cm: Horizonte Bh3}


Preto (10YR2/1) com matéria orgânica bem distribuída; pontuações bruno avermelhadas; arenoso (areia fina) e siltoso pela matéria orgânica; maciço; muito poroso. Limite nítido com o horizonte inferior superior.

\section{5 cm: Horizonte Bh/E}

Preto (10YR2/1) com pequenos domínios alongados de areia lavada (10YR3/1); arenoso (areia grosseira); maciço. Limite nítido com o horizonte superior.

\section{TRINCHEIRA 9}

\section{0-6cm: Horizonte Ae1 (contínuo na trincheira)}

Cinza escuro (10YR4/1); arenoso (areia fina); grãos soltos nas faces dos grânulos; poroso.

\section{6-12cm: Horizonte Ae2 (contínuo na trincheira)}

Cinza escuro (10YR3/2); arenoso (areia fina); maciço que desfaz em granular, grãos soltos nas faces dos grânulos; poroso. Transição gradual com o horizonte superior.

\section{2-36cm: Horizonte Ae3 (contínuo na trincheira)}

Cinza (10YR6/1); arenoso; grãos soltos e grânulos de matéria orgânica; poroso. Transição gradual para o horizonte superior.

\section{6-51cm: Horizonte A/E (contínuo na trincheira)}

Cinza claro (10YR7/1); muito arenoso (areia fina); grãos soltos e grânulos de matéria orgânica; muito poroso. Transição gradual para o horizonte superior; poucas raízes.

\section{1-69cm: Horizonte Bh1 (contínuo na trincheira)}

Cinza brunado (10YR5/2); arenoso (areia fina); grãos soltos e grânulos; poroso; Limite nítido com o horizonte superior; poucas raízes grossas.

\section{9-83cm: Horizonte Bhs (contínuo na trincheira)}

Bruno empretecido (10YR3/3, úmido) com matéria orgânica bem distribuída; arenoso; maciço que desfaz em granular; poroso. Transição gradual para o horizonte superior; poucas raízes finas.

\section{3-92cm: horizonte Bh2 (jusante)}

Preto (10YR2/1), com matéria orgânica bem distribuída; arenoso; aspecto maciço que desfaz em granular fraca; poroso. Limite nítido interpenetrado com o horizonte superior; poucas raízes.

92-129cm: Horizonte B/Bhs (contínuo na trincheira) 
Bruno empretecido (7,5YR 3/2) a bruno; arenoso; maciço que desfaz em granular; poroso. A matéria orgânica impregna o horizonte em frentes convolutas, sendo que na jusante o horizonte é mais impregnado pela matéria orgânica. Limite vertical nítido com B/E de montante e lateral com Bh2 de jusante; poucas raízes.

127-160cm: Horizonte B/E (descontínuo, de forma convoluta é discordante sobre o B/Bhs, montante)

Cor heterogênea, Bruno escuro (7,5YR5/6, dominante) com domínios arenosos de cor branca (7,5YR 8/1); arenoso (areia fina); granular e grãos soltos nos domínios arenosos; poroso. Transição difusa com o horizonte superior.

160-175cm: Horizonte Bh/E(descontínuo, de forma convoluta é discordante sobre B/Bhs, jusante)

Cor heterogênea cinza clara (7,5YR7/0) dominante e bruno empretecida (7,5YR4/4) dominante; grãos soltos, nos domínios arenosos e, granular, nos domínios mais orgânicos; poroso. Limite nítido com o horizonte superior.

\section{5-192cm: Horizonte IIC/Bs (jusante)}

Cor heterogênea amarelada (10YR7/8), dominante, e cinza clara (7,5YR7/0); arenoso (areia grossa); maciço; poroso; limite nítido com o horizonte superior.

\section{2-197cm: Horizonte Bh3 (contínuo na trincheira)}

Bruno acinzentado escuro (10YR3/2, muito úmido) com matéria orgânica bem distribuída, domínios esbranquiçados de areia lavada (grosseira do metarenito alterado); arenoso; maciço; poroso. Limite nítido com o horizonte superior.

\section{7-205cm: Horizonte Bh/IIC (contínuo na trincheira)}

Bruno acinzentado escuro (10YR3/2, muito úmido) com matéria orgânica bem distribuída, pontuações de areia lavada (grosseira); arenoso; estrutura petrográfica dominante; porosidade entre as bandas da rocha. Limite nítido com o horizonte superior.

\section{5+cm: Horizonte IIC (contínuo na trincheira)}

Metarenito alterado com textura petrográfica: cor branca dominante com interpenetrações de material orgânico (10YR 3/2); justaposição de cores amareladas (10YR6/8), acinzentadas (7YR7/0). Limite nítido com o horizonte superior.

\section{TRINCHEIRA 6}




\section{0-4 cm: Horizonte Ae1}

Cinza (10YR5/1); arenoso (areia fina); grãos soltos podem estar presentes nas faces da estrutura granular, grânulos de matéria orgânica; poroso; transição gradual para o horizonte inferior pelo escurecimento da cor, muitas raízes.

\section{4-14 cm: Horizonte Ae2}

Bruno acinzentado escuro (10YR3/2, úmido); arenoso com um pouco de argila; granular, grãos soltos e grânulos de matéria orgânica; poroso. Transição gradual com o horizonte superior; raízes finas e médias.

\section{4-61 cm: Horizonte Bhs}

Preto acinzentado (10YR3/1), com matéria orgânica distribuída de maneira contínua; arenoso com um pouco de argila; maciço que desfaz em granular; poroso, com canais preenchidos por matéria orgânica. A passagem deste horizonte para o inferior se faz em uma transição de $10 \mathrm{~cm}$ cuja cor é bruno amarelada empretecida (10YR4/6). O limite é nítido com o horizonte superior.

\section{$71-80 \mathrm{~cm}$ Horizonte B1}

Cor heterogênea variando do bruno escuro (7,5YR5/6) ao bruno amarelado (10YR5/6) e bruno amarelado empretecido (10YR4/6); arenoso; maciço que desfaz em granular; poroso. Limite interpenetrado com o horizonte superior.

\section{0-90 cm: Horizonte Bh2}

Bruno acinzentado (10YR3/1) a cinza esbranquiçado (10YR8/2) com matéria orgânica distribuída de maneira contínua; arenoso com um pouco de argila; maciço; poroso. Limite interpenetrado com o horizonte superior

\section{0-109 cm: Horizonte B2}

Amarelo (10YR7/6) com manchas mais escuras; arenoso com um pouco de argila; maciço; poroso com alguns canais com matéria orgânica. Na parte superior desse horizonte observa-se uma transição de cor amarela (10YR7/8) areno-siltosa, com domínios cinza empretecidos no limite superior interpenetrando no horizonte acima, configurando um horizonte B1.

\section{9-133 cm: Horizonte Bh}

Bruno amarelado empretecido (10YR4/4) com domínios amarelos (10YR7/6); arenoso com um pouco de argila; maciço; poroso. Limite abrupto com o horizonte superior.

\section{3-139 cm: Horizonte Bh/IIC}


Horizonte de alteração do metarenito, fortemente impregnado pela matéria orgânica: bruno acinzentado escuro (10YR3/2) com domínios amarelo-pálido (10YR7/6); arenoso com um pouco de argila; poroso. Transição gradual com o horizonte superior.

\section{9-146 cm: Horizonte IIC}

Metarenito alterado com textura petrográfica. Cor branca com domínios ferruginosos avermelhados (10YR7/2), amarelados, às vezes, impregnação por matéria orgânica (10YR4/3); formando um horizonte de transição C/Bh; quartzoso e micáceo. Limite abrupto com o horizonte superior; quartzoso e micáceo. Limite abrupto com o horizonte superior.

\section{TRINCHEIRA 4 (aparecimento do Bh em profundidade)}

\section{0-3 cm: Horizonte Ae1}

Cinza claro (10YR7/2); arenoso (areia fina); grãos soltos de areia lavada e granular (grânulos de matéria orgânica); muito poroso; muitas raízes.

\section{3-10 cm: Horizonte Ae2}

Bruno claro (10YR6/3); arenoso; grãos soltos de areia lavada e granular (grânulos de matéria orgânica); muito poroso; muitas raízes. Transição gradual com o horizonte superior.

\section{0-15 cm: Horizonte Bhs}

Bruno escuro (10YR3/3), arenoso; maciço que desfaz em granular; poroso; raízes poucas. Limite nítido com o horizonte superior.

\section{5-43 cm: Horizonte B1}

Horizonte de cor heterogênea, bruno (10YR5/3) com domínios de matéria orgânica bruno acinzentada escura (10YR4/2) e pontuações bruno avermelhadas (2.5YR4. 5/3); arenoso; maciço; poroso. Limite nítido interpenetrado com o horizonte superior.

\section{3-51 cm: Horizonte B2}

Amarelo (10YR7/8) com domínios cinza empretecidos no limite inferior do horizonte; arenoso; maciço; poroso. Transição gradual com limite difuso para o horizonte superior.

\section{1-63 cm: Nível de cascalho}


Cascalhos de quartzo de até $1 \mathrm{~cm}$ em meio a matriz amarelo pálido (10YR8/3) com domínios amarelos (10YR7/8); arenosa. Limite abrupto com o horizonte superior.

\section{3-66 cm: Horizonte IIC1}

Metarenito alterado com textura petrográfica e estrutura litológica maciça e bandada, com pequenos veios de quartzo (face sul). Cor heterogênea, amarela (10YR7/8 dominante e 10YR7/6), amarela-avermelhada (7YR6/8), domínios cinza escuro. Quartzoso e micáceo. Limite abrupto ressaltado pelo aparecimento do cascalho.

\section{6-85 cm: Horizonte IIC2}

Metarenito alterado com textura petrográfica e estrutura litológica bandada, com justaposição de cores amarela-avermelhada (7YR6/8, dominante), amarela (2,5Y8/8) e bruno-acinzentada empretecida (10YR3/2); quartzoso e micáceo; porosidade forte entre as bandas entre as quais aparece o material orgânico (10YR3/2). Transição gradual pela diminuição da fase vermelha.

\section{5-129+ cm: Horizonte IIC3-106-122 cm: Bh/IIC}

IIC3:Metarenito alterado com textura petrográfica e estrutura litológica bandada; cor branca com pontuações ferruginosas avermelhadas; quartzoso e micáceo. Limite abrupto com o horizonte superior, sublinhado pela presença de matéria orgânica (10YR3/2).

Bh/IIC: Horizonte de cor 10YR3/1. A matéria orgânica penetra nas bandas do metarenito alterado e impregna a alteração hidromórfica adjacente. Tem formato em cunha que avança para a montante do perfil.

\section{TRINCHEIRA 2}

\section{0-4 cm: Horizonte Ae1}

Esbranquiçado (10YR8/2) com grânulos cinza claro (10YR7/2); arenoso; grãos soltos e poucos grânulos; poroso.

\section{4-21 cm: Horizonte A12}

Bruno-amarelado (10YR5/4); areno-argiloso; granular com alguns grãos soltos disjuntos dos materiais finos; poroso; poucas raízes. Transição gradual pelo empalidecimento da cor.

21-61 cm: Nível de cascalho heterogêneo 
Cascalhos de tamanho e mineralogia variada em meio a matriz bruno-empretecida (7,5YR4/2) e amarelo-brunada (10 YR 6/8): bandas de quartzito ferruginizado, blocos de couraça ferruginosa, fragmentos subangulares de quartzo ferruginizados e não ferruginizados; matriz arenosa, porosa. Limite abrupto com o horizonte superior.

\section{1-76 cm: Nível de cascalho de veio}

Cascalhos de diâmetro homogêneo; quartzosos, ferruginizados ou não, em meio a matriz amarelo-brunada (10YR 6/8) arenosa; porosa.

\section{6-133 cm: Horizonte IIC1}

Metarenito alterado, textura petrográfica, friável; com fases justapostas: amarela (10YR7/8, dominante), e (10YR7/6) e amarela-avermelhada (7YR6/8) amareladas (10YR7/8). Arenoso/ micáceo. Na face sul o material está ferruginizado. Limite nítido com o horizonte superior.

\section{3-158 cm: Horizonte IIC2}

Metarenito alterado com textura petrográfica. Em fases justapostas, tem cores amarela-avermelhada (7YR6/8 dominante), esbranquiçadas (10YR5/8); amarelas (10YR8/8); micáceo.

\section{Comentário}

No geral tem aspecto de solo mais laterítico. A alteração mostra níveis mais ferruginosos e mais claros percebe-se níveis menos alterados formando linhas de material grosseiro (dentro da escala de observação a olho nu) indicando autoctonia desta fase cascalhenta. Aparecem também cascalhos com estrutura laminar (bandas ferruginosas de quartzitos), fragmentos de quartzo ferruginizado e não, e fragmentos de couraça ferruginosa. Essa parte parece ser um material transportado dada a heterogeneidade mineralógica, distribuição dos materiais e da granulometria do cascalho. Assim, pode-se acreditar que o perfil tem parte cujo material de origem é de transporte e parte autóctone vindos da alteração da rocha.

\section{TRINCHEIRA 1}

\section{0-3 cm: Horizonte A11}

Bruno (10YR5/3); arenoso; granular; poroso; muitas raízes.

\section{3-18 cm: Horizonte A12}


Cor heterogênea, bruno-amarelada (10YR5/6 a 10YR5/4); arenoso; maciço que desfaz em granular; poroso. Transição gradual para o horizonte superior pelo empretecimento da cor.

\section{8-32cm: Horizonte A/B1}

Bruno-amarelado (10YR5/6); arenoso; maciço que desfaz em granular; muito poroso com alguns canais preenchidos por matéria orgânica. Transição gradual para o horizonte superior.

\section{2-61 cm: Nível de cascalho}

Materiais ferruginizados (quartzos, fragmentos de couraça ferruginosa), seixos arredondados ferruginizados em meio a uma matriz de cor heterogênea, brunoamarelada (10YR5/6), bruno-empretecida (7,5YR4/2) e amarelo-brunada (10YR6/8); matriz arenosa e granular. Limite abrupto com o horizonte superior.

\section{1-77 cm: Horizonte IC1}

Filito alterado em material variegado vermelho claro (2,5YR6/8), amareloavermelhado (7,5YR5/8); arenoso (areia grossa ferruginizada); textura petrográfica.

\section{7-109 cm: Horizonte IC2}

Filito alterado em material variegado bruno-amarelado (10YR5/8) e amarelo pálido (10YR8/3); micáceo e com material quartzoso grosseiro; textura petrográfica. Limite nítido com o horizonte superior.

\section{9-137 cm: Veio de quartzo}

Quartzo com película de ferruginização.

\section{7-158 + cm: Horizonte IC3}

Filito alterado, ainda, com textura petrográfica e estrutura litológica; material em fases justapostas: amarelas clara (10YR8/4), amarelas escura (10YR5/8), e avermelhadas (7,5YR5/8). Argiloso. Limite abrupto com o nível superior.

\section{Comentários:}

Um pouco acima da trincheira 4, na direção de montante da seqüência, aparecem os níveis de cascalho. As trincheiras 3 e 1 se enquadram nos comentários feitos para a trincheira 2. 